\title{
PEMANFAATAN BIOMASA KANGKUNG AIR (IPOMOEA AQUATICA FORSK) UNTUK ADSORPSI PEWARNA TEKSTIL
}

\author{
Elyz Zaqiyatul , Eko Malis*, Rosyid Ridho \\ email korespondensi : malisgsn@gmail.com \\ Program Studi Kimia, Fakultas Matematika dan Ilmu Pengetahuan Alam \\ Universitas PGRI Banyuwangi
}

\begin{abstract}
ABSTRAK
Zat warna yang digunakan pada umumnya beragam jenis dan golongannya tergantung dari jenis seratnya. Namun beberapa zat warna tekstil mengandung polutan berupa logam berat dan atau "intermediate dye" yang berbahaya. Logam berat tersebut antara lain adalah tembaga, nikel, krom, merkuri dan kobalt. Salah satu alternatif penanganan limbah adalah penggunaan adsorben sebagai pengikat atau pengadsorp bahan buangan berbahaya yaitu logam dan molekul organik yang tidak mudah terdegradasi.

Peroses adsorben zat pewarna tekstil meliputi preparasi biomassa batang kangkung air, pembuatan induk pewarna tekstil, preparasi sampel larutan induk pewarna tekstil lila(wantex), penentuan panjang gelombang maksimum pewarna tekstil lila, pembuatan kurva standar untuk spektroskopi UV-VIS, dan penentuan pengaruh adsorpsi larutan pewarna tekstil lila terhadap biomasa kangkong air.

Panjang gelombang maksimum untuk larutan standar pewarna tekstil lila 100 ppm menggunakan Spektofotometer UV-VIS yaitu $536 \mathrm{~nm}$, Untuk mendapatkan panjang gelombang yang lebih optimum di lakukan scanning lagi dengan interfal 2 dan di dapat panjang gelombang maksimum $536 \mathrm{~nm}$, larutan standar berasal dari larutan induk pewarna tekstil lila 100 ppm diencerkan menjadi $50 \mathrm{~mL}$ dengan konsentrasi yaitu 5, 10, 20, 30, 40, 50, 60, 70, 80, 90, 100 ppm. Semakin besar luas permukaan adsorben semakin besar pula kapasitas suatu adsorben dalam mengadsorpsi suatu adsorbat.
\end{abstract}

Kata kunci: zat warna, adsorben, biomasa , intermediate dye,UV-VIS. 


\section{PENDAHULUAN}

Zat warna yang digunakan pada umumnya beragam jenis dan golongannya tergantung dari jenis seratnya. Namun beberapa zat warna tekstil mengandung polutan berupa logam berat dan atau "intermediate dye" yang berbahaya. Logam berat tersebut antara lain adalah tembaga, nikel, krom, merkuri dan kobalt. Polutan tersebut pada akhirnya akan berada dalam perairan umum, karena pada proses pencelupan hanya sebagian zat warna yang akan terserap oleh bahan tekstil dan sisanya $(2-50 \%)$ akan berada dalam pembilas (efluen) tekstil, sehingga apabila konsentrasinya cukup besar, maka dapat mencemari lingkungan. Keberadaan kandungan logam berat dalam perairan atau sungai akibat aktivitas industri tekstil tentu saja membutuhkan penanganan serius mengingat air sungai merupakan sumber utama berbagai kegiatan pertanian, perikanan bahkan di beberapa kota besar dapat merupakan sumber air minum. Salah satu alternatif penanganan limbah adalah penggunaan adsorben sebagai pengikat atau pengadsorp bahan buangan berbahaya yaitu logam dan molekul organik yang tidak mudah terdegradasi. Penggunaan adsorben relatif sederhana dan dapat diregenerasi (Endang W Laksono dkk, 2006).

Metode adsorpsi telah dikembangkan menggunakan biomassa tumbuhan yang dikenal dengan fitofiltrasi. Dasar pemikiran dari fitofiltrasi adalah dengan menggunakan biomassa tumbuhan yang telah mati sebagai pengikat ion logam (Gamez, et al., 1999). Metode adsorpsi menggunakan biomassa merupakan metode yang efektif dalam mengikat ion logam berat, baik anionik maupun kationik.
Penelitian Seregeg dkk (2005) menunjukkan bahwa tanaman kangkung air termasuk salah satu tanaman yang mudah menyerap logam berat dari media tumbuhnya. Hal serupa juga dilakukan oleh Prasetyawati (2007) di perairan taman wisata Wendet Malang. Hasil yang diperoleh menunjukkan bahwa kangkung air (Ipomoea aquatica Forsk) mampu menyerap logam berat yaitu merkuri $(\mathrm{Hg})$ pada batang 0,69 ppm, daun tua 0,61 ppm dan daun muda 0,1 ppm. Menurut Marianto (2009) kandungan gizi dalam $100 \mathrm{~g}$ kangkung air segar adalah protein 3,90 g dan karbohidrat 4,40 g. Protein tersusun dari beberapa asam amino yang apabila larut dalam air gugus karboksilat $(\mathrm{COOH})$ akan melepaskan ion $\mathrm{H}_{+}$dan gugus amina $\left(\mathrm{NH}_{2}\right)$ akan menerima ion $\mathrm{H}_{+}$ membentuk $\mathrm{NH}_{3}$ (Poedjiadi, 2007). Ion tersebut sangat reaktif untuk berikatan dengan ion-ion logam yang larut dalam air termasuk kromium.

Proses adsorpsi ion logam menggunakan biomassa tumbuhan dipengaruhi oleh beberapa faktor diantaranya adalah $\mathrm{pH}$ larutan dan waktu kontak. Efisiensi adsorpsi optimum untuk ion logam kationik pada $\mathrm{pH}$ 5-6 dan efisiensi adsorpsi optimum untuk logam anionik pada $\mathrm{pH}$ 2. Dengan demikian biomassa dapat digunakan untuk mengadsorpsi ion logam kationik dan anionic (Dokken, et al.,1996).

Biomassa adalah pemanfaatan material padat bahan alam untuk mengadsorpsi logam berat yang terlarut dalam larutan. Metode ini sangat baik dalam mengolah limbah industri yang mengandung logam berbahaya dan memberikan kapasitas penyerapan yang tinggi. Biomassa merupakan bahan yang berasal dari zat-zat organik yang dapat diperbaharui dan dari makhluk hidup baik hewan maupun tumbuhan. Beberapa bahan biomassa adalah ganggang laut,bakteri, alfalfa dan portulaca oleracea 
(Kartohardjono, 2008). Malkoc (2007) menjelaskan bahwa biomassa yang sudah digunakan sebagai adsorben diantaranya adalah ganggang hijau, serbuk gergaji dari kayu, ampas tebu, lempung, karbon aktif, rumput gajah, daun enceng gondok, dan daun teh. Keuntungan menggunakan biomassa tersebut adalah memerlukan biaya yang lebih ekonomis. Menurut penelitian yang dilakukan Kohar dkk (2005) bahwa kangkung air adalah salah satu tanaman yang mudah menyerap logam berat dari media tumbuhnya. Penelitian lainnya menjelaskan bahwa di perairan taman wisata Wendet Malang menunjukkan bahwa kangkung air (Ipomoea aquatica Forsk) mampu menyerap logam berat yaitu merkuri $(\mathrm{Hg})$ pada batang 0,69 ppm, daun tua 0,61 ppm dan daun muda 0,1 ppm (Prasetyawati, 2007). Kandungan protein dan karbohidrat dalam 100 g kangkung air segar adalah 3,90 g dan 4,40 g (Marianto, 2009). Hal tersebut menyebabkan kangkung air berpotensi sebagai biomassa. Protein tersusun dari beberapa asam amino yang apabila larut dalam air gugus karboksilat $(\mathrm{COOH})$ akan melepaskan ion $\mathrm{H}_{+}$dan gugus amina $\left(\mathrm{NH}_{2}\right)$ akan menerima ion $\mathrm{H}_{+}$ membentuk $\mathrm{NH}_{3}$. Ion tersebut sangat reaktif untuk berikatan dengan ion-ion logam yang larut dalam air termasuk kromium (Poedjiadi, 2007). Gugus fungsional dari rantai selulosa adalah gugus hidroksil $(-\mathrm{OH})$. Gugus sini dapat berinteraksi dengan gugus lain yaitu $-\mathrm{O}$, $\mathrm{N}$, dan $-\mathrm{S}$ membentuk ikatan hidrogen. Ikatan yang terjadi antara ion logam dengan selulosa dapat terjadi melalui ikatan hidrogen dan gaya Van der Walls. Hal inilah yang menyebabkan tanaman kangkung air dapat dimanfaatkan sebagai bioadsorben logam berat. Gugus-OH selulosa menyebabkan permukaan selulosa menjadi hidrofilik sehingga mudah larut dalam air (Hawab, 2004). Protein adalah senyawa organik kompleks yang terdiri atas unsur-unsur karbon (50-55\%), hidrogen (7\%), oksigen (23\%), dan nitrogen (16\%) (Deman, 1997). Protein merupakan polipeptida yang mempunyai bobot molekul bervariasi antara 5000 sampai jutaan. Dengan cara hidrolisis oleh asam atau enzim, protein akan menghasilkan asam-asam amino (Poedjiadi, 2007). Dalam molekul protein terdapat 20 jenis asam amino. Asam amino ialah asam karboksilat yang mempunyai gugus amino. Asam amino yang terdapat sebagai komponen protein mempunyai gugus $-\mathrm{NH}_{2}$ pada atom karbon $\alpha$ dari posisi gugus - $\mathrm{COOH}$. Asam-asam amino ini terikat satu dengan yang lain oleh ikatan peptida (Poedjiadi, 2007). Asam amino apabila larutan dalam air dapat membentuk ion yang bermuatan positif dan negatif (zwitterion) atau ion amfoter. Gugus karboksilat akan melepaskan ion $\mathrm{H}_{+}$dan gugus amina menerima ion $\mathrm{H}_{+}$. Keadaan ini sangat tergantung pada $\mathrm{pH}$ larutan. Apabila larutan asam amino dalam air ditambahkan basa maka asam amino akan membentuk ion -COO karena konsentrasi ion $\mathrm{OH}$ yang tinggi mampu mengikat ion-ion $\mathrm{H}_{+}$yang terdapat pada gugus $-\mathrm{NH}_{3+}$. Apabila larutan asam amino ditambahkan asam, maka konsentrasi ion $\mathrm{H}_{+}$yang tinggi mampu berikatan dengan ion -COO sehingga terbentuk gugus $-\mathrm{COOH}$ (Poedjiadi, 2007). Karbohidrat merupakan zat-zat yang sangat melimpah di alam, baik dalam tumbuhan, hewan maupun dalam tubuh manusia. Hal ini dikarenakan lebih dari separuh senyawa-senyawa organik yang ditemukan di alam dalam bentuk karbohidrat, seperti selulosa yang merupakan karbohidrat dalam tumbuhan yang mempunyai fungsi sebagai kerangka 
batang dan daun (Hawab, 2004). Karbohidrat yang dapat terhidrolisa lebih dari 10 molekul monosakarida.Misalnya pati dan selulosa. Selulosa merupakan molekul glukosa yang dapat membentuk sebuah rantai panjang tidak bercabang seperti pada amilosa. Unit-unit glukosa dalam selulosa terikat melalui ikatan $\beta-1-4$ glikosidik (Lehninger, 1982).

Selulosa ditemukan sebagai dinding sel tumbuhan, tidak larut dalam air, ditemukan banyak pada batang, dahan, tangkai, daun, dan hampir semua jaringan tumbuhan. Kayu, katun, kapas, bambu, dan serat tumbuhan mengandung selulosa sebesar (98\%-99\%) (Hawab, 2004). Gugus fungsional dari rantai selulosa adalah gugus hidroksil $(-\mathrm{OH})$, gugus ini dapat berinteraksi dengan gugus lain yaitu $-\mathrm{O}$, $\mathrm{N}$, dan $-\mathrm{S}$ membentuk ikatan hidrogen. Ikatan yang terjadi antara ion logam dengan ion $\mathrm{O}$. dari gugus hidroksil $(-\mathrm{OH})$ dapat berikatan dengan ion logam yang larut dalam air. Struktur rantai selulosa distabilkan oleh ikatan hidrogen yang kuat disepanjang rantai. Setiap rantai selulosa diikat bersama-sama dengan ikatan hidrogen (Hawab, 2004). Kemungkinan adanya gugus fungsional - $\mathrm{OH}$ yang berperan dalam pengikatan ion logam yang terkandung dalam senyawa karbohidrat pada biomassa daun enceng gondok. Beberapa gugus - $\mathrm{OH}$ juga dapat bertindak sebagai atom donor. Dengan demikian, deprotonasi pada gugus $-\mathrm{OH}$ juga dapat berperan dalam pengikatan ion logam (Al Ayubi, 2008).

Adsorpsi adalah proses berpindahnya komponen dari suatu fasa menuju permukaan yang lain atau peristiwa penyerapan suatu zat pada permukaan zat lain sehingga terjadi perubahan konsentrasi pada permukaan. Adsorpsi akan terjadi karena adanya perbedaan energi potensial antara permukaan adsorben dan zat yang terserap (Ketaren, 2008). Adsorpsi menggunakan istilah adsorbat dan adsorben. Zat yang menyerap disebut adsorben sedangkan ion, atom atau molekul yang diserap disebut adsorbat (Kriswiyanti dan Danarto, 2007). Berdasarkan sifatnya, adsorpsi dapat digolongkan menjadi adsorpsi fisik dan kimia. Adsorpsi fisik adalah adsorpsi yang melibatkan gaya intermolekul (gaya Van der Walls dan ikatan hidrogen) antar adsorbat dan substrat (adsorben) (Atkins, 1999). Adsorpsi kimia adalah adsorpsi yang melibatkan ikatan kovalen. Ikatan tersebut terjadi sebagai hasil dari pemakaian bersama elektron oleh adsorben dan adsorbat. Dalam adsorpsi kimia partikel melekat pada permukaan dengan membentuk ikatan kimia yaitu ikatan kovalen. Sifat adsorpsinya adalah irreversible dan membentuk lapisan monolayer (Atkins, 1999). Proses adsorpsi melibatkan berbagai macam gaya yaitu gaya Van der Walls, ikatan hidrogen, dan ikatan kovalen. Gaya Van der Walls timbul dari pergerakan awan elektron dari molekul-molekul atau atom-atom yang berdekatan. Pergerakan ini menimbulkan dipol-dipol yang muatannya berlawanan dalam atom yang menyebabkan adanya tarikan lemah antara atom atau molekul 
satu sama lain (Khoirunnisa, 2005). Ikatan hidrogen terjadi apabila atom hidrogen terikat oleh dua atau lebih atom lain yang memiliki keelektronegatifan tinggi seperti atom $\mathrm{N}, \mathrm{O}$, dan $\mathrm{F}$.

Kapasitas adsorpsi ion oleh adsorben adalah jumlah gugus yang dapat dipertukarkan dalam adsorben. Kapasitas penukaran adsorpsi ion dari suatu adsorben ialah jumlah ion yang dapat ditukar untuk setiap $1 \mathrm{~g}$ adsorben kering, atau jumlah ion yang dapat ditukar untuk setiap $1 \mathrm{~mL}$ adsorben basah. Besarnya nilai kapasitas adsorpsi suatu adsorben bergantung dari jumlah gugus-gugus ion yang dapat ditukarkan yang terkandung dalam setiap $g$ adsorben tersebut. Semakin besar jumlah gugus-gugus tersebut semakin besar pula nilai kapasitas adsorpsinya (Underwood, 2002). Energi adsorpsi merupakan jumlah energi elektrostatik dan energi adsorpsi kimia yang terlibat dalam adsorpsi yang dapat dinyatakan sebagai energi bebas standar adsorpsi. Menurut Adamson (1990) besarnya energi adsorpsi yang menyertai adsorpsi fisika sekitar $10 \mathrm{~kJ} / \mathrm{mol}$ dan lebih rendah dari energi adsorpsi kimia. Pada adsorpsi kimia terjadi pembentukan dan pemutusan ikatan, sehingga energi adsorpsinya berada pada kisaran yang sama dengan reaksi kimia. Selain itu ikatan antara adsorben dengan adsorbat cukup kuat sehingga tidak terjadi spesiasi, karena zat yang teradsorpsi menyatu dengan adsorben membentuk satu lapisan monolayer dan relatif bersifat irreversibel. Menurut Adamson (1990) batas minimal energi adsorpsi kimia adalah 20,92 kJ/mol, sedangkan menurut Oscik (1982) perkiraan harga energi adsorpsi kimia berkisar antara 80-650 kJ/mol dan menurut Lyman dkk (1995) besar energi adsorpsi kimia adalah $42-420 \mathrm{~kJ} / \mathrm{mol}$.

Zat warna tekstil umumnya dibuat dari senyawa azo dan turunannya yang merupakan gugus benzena. Diketahui bahwa gugus benzena sangat sulit didegradasi, kalaupun dimungkinkan dibutuhkan waktu yang lama. Senyawa azo bila terlalu lama berada di lingkungan, akan menjadi sumber penyakit karena sifatnya karsinogen dan mutagenik. Karena itu perlu dicari alternatif efektif untuk menguraikan limbah tersebut. Pengolahan limbah pewarna pada tekstil sulit dilakukan karena struktur aromatik pada zat warna yang sulit dibiodegradasi, khususnya zat warna reaktif karena terbentuknya ikatan kovalen yang kuat antara atom $\mathrm{C}$ dari zat warna dengan atom $\mathrm{O}, \mathrm{N}$ atau $\mathrm{S}$ dari gugus hidroksi, amina atau thiol dari polimer Pewarna tersebut memiliki gugus kromofor azo sehingga disebut pewarna azo. Pewarna reaktif ini banyak digunakan dalam proses pencelupan bahan tekstil.

Zat warna azo adalah senyawa yang paling banyak terdapat dalam limbah tekstil, yaitu sekitar $60 \%-70 \%$ (Endang W, 2009, ) . Senyawa azo memiliki struktur umum $\mathrm{R}-\mathrm{N}=\mathrm{N}-\mathrm{R}^{\prime}$, dengan $\mathrm{R}$ 
dan R' adalah rantai organik yang sama atau berbeda. Senyawa ini memiliki gugus $-\mathrm{N}=\mathrm{N}-$ yang dinamakan struktur azo. Senyawa azo dapat berupa senyawa aromatik atau alifatik. Senyawa azo aromatik bersifat stabil dan mempunyai warna menyala. Kenaikan suhu atau iradiasi, ikatan nitrogen dan karbon akan pecah secara simultan melepaskan gas nitrogen dan radikal. Dengan demikian, beberapa senyawa azo alifatik digunakan sebagai inisiator radikal. Spektroskopi UVVIS berkaitan dengan proses transisi elektron dalam molekul. Informasi yang didapat cenderung untuk molekul keseluruhan bukan bagian-bagian molekulnya (Khopkar, 2003). Spektrofotometer UV-VIS digunakan untuk penentuan konsentrasi senyawa-senyawa yang dapat menyerap radiasi pada daerah ultraviolet $(200-400 \mathrm{~nm})$ atau daerah visibel $(400-800$ nm) (Sastrohamidjojo, 1991). Metode spektrofotometri untuk analisis kuantitatif suatu senyawa didasarkan pada pengukuran terjadinya serapan radiasi elektromagnetik oleh molekul pada panjang gelombang yang spesifik. Hubungan antar panjang jalan medium yang dilewati oleh intensitas cahaya dan hubungan antar serapan radiasi dengan konsentrasi dikenal dengan Hukum LambertBeer, yaitu (Vogel, 1990). Absorpsivitas molar ( $\varepsilon$ ) dan absorpsivitas (a) adalah suatu konstanta dan nilainya spesifik untuk jenis zat dan panjang gelombang tertentu, sedangkan tebal media (sel) dalam prakteknya tetap. Dengan demikian absorbansi suatu spesies akan merupakan fungsi linier dari konsentrasi, sehingga dengan mengukur absorbansi suatu spesies konsentrasinya dapat ditentukan dengan membandingkannya dengan konsentrasi larutan standar (Azis, 2007). Analisa kuantitatif $\mathrm{Cr}(\mathrm{VI})$ dilakukan dengan cara spektrofotometer menggunakan pereaksi difenilkarbazida sebagai reagen pengkompleks. Tahapan yang dilakukan adalah larutan sampel diasamkan menggunakan $\mathrm{H}_{2} \mathrm{SO}_{4}$ encer kemudian ditambahkan reagen difenilkarbazida yang menghasilkan kompleks 28 warna merah tua apabila konsentrasi kromium tinggi dan menghasilkan kompleks warna lembayung (ungu) apabila konsentrasi kromium rendah (Vogel, 1990). Pada saat reaksi kromat direduksi menjadi $\mathrm{Cr}(\mathrm{II})$ dan kemudian terbentuk menjadi difenilkarbazon, hasil reaksi yang terjadi menghasilkan kompleks dengan warna yang khas. Reaksi yang terjadi adalah sebagai berikut (Vogel, 1990): 

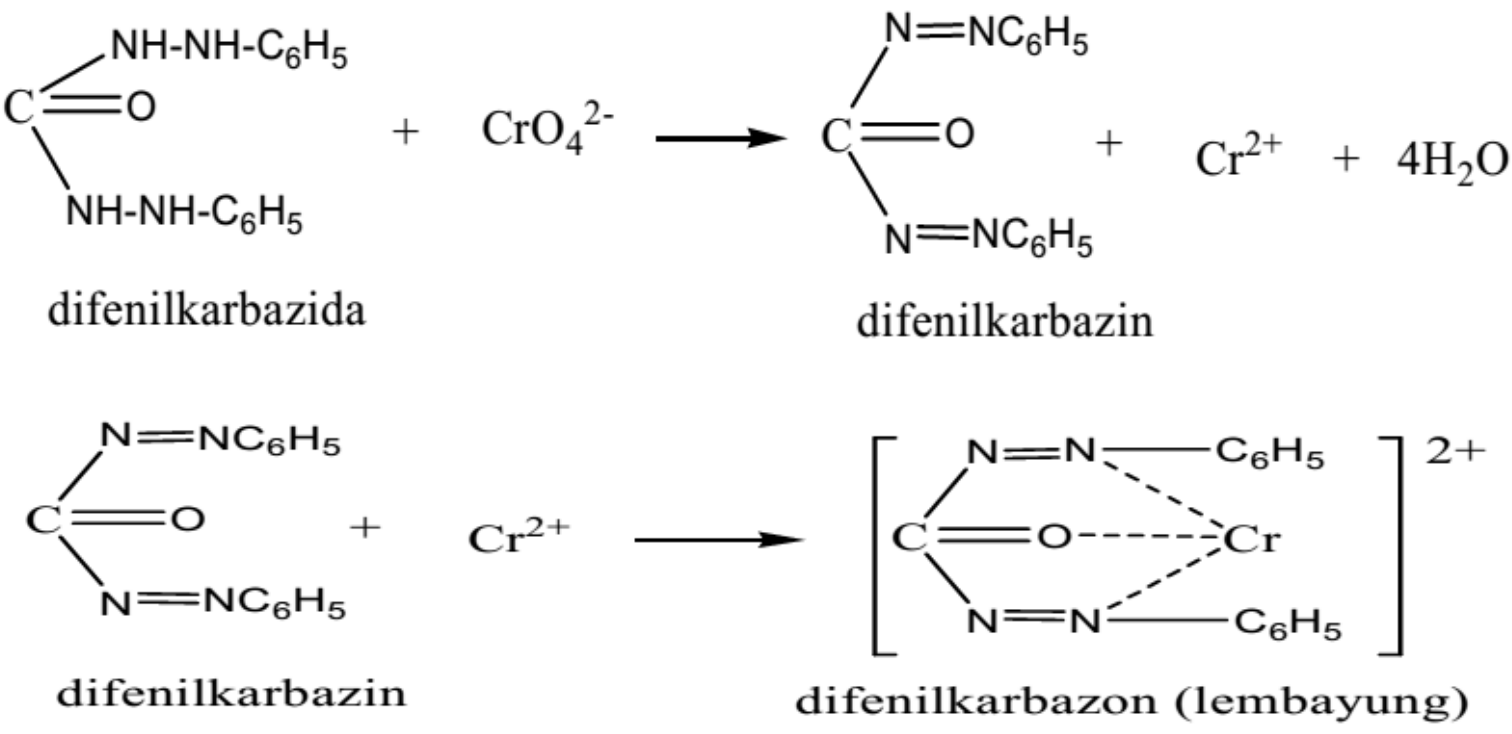

Dari latar belakang diatas maka dilakukan penelitian Pengaruh Ketetimbangan Adsorpsi Pewarna Tekstil Pada Biomasa Kangkung Air (Ipomoea Aquatica Forsk)

\section{METODE PENELITIAN}

\section{Alat danBahan}

\subsection{Alat yang digunakan dalam}

\section{penelitian}

Alat-alat yang digunakan dalam penelitian ini adalah alat-alat gelas, oven dengan merek (memmert), pengaduk magnet, shaker, ayakan 270 mesh, blender, kertas saring, $\mathrm{pH}$ meter, spektrofotometer IR, dan seperangkat spektroskopi UV-VIS merek Simadzu.

\subsection{Bahan yang digunakan dalam penelitian}

Bahan yang digunakan dalam penelitian ini adalah batang dari tanaman kangkung air, aquadest, pewarna tekstil (wenter pakaian) merek wantex padi gunting dengan warna lila 21, $\mathrm{AgNO}_{3}$,

$\mathrm{HCl}$,

\subsection{Preparasi Biomassa Batang} Kangkung Air (Al-Ayubi, 2008)

Tanaman kangkung air yang diperoleh dari desa Sidodadi Kabupaten Banyuwangi. Kemudian dihilangkan bagian daun dan akar. Batang kangkung air yang telah bersih dikeringkan dengan oven pada suhu 100 oC selama 24 jam. Sampel yang telah kering kemudian ditumbuk sampai halus dan disaring dengan ayakan berukuran 270 mesh.

Sampel direndam dan disheker dengan $\mathrm{HCl} 0,01 \quad \mathrm{M}$ selama 1 jam untuk melarutkan logam-logam yang terikat pada biomassa. Sampel direndam dengan 
aquades sampai filtrat yang diperoleh tidak terdapat ion Cl- sisa rendaman.

Kemudian dikeringkan dengan oven pada suhu $50-60$.C sampai diperoleh berat konstan.

\subsection{Pembuatan Larutan Induk Pewarna Tekstil}

Pewarna tekstil lila (PTm) ditimbang sebanyak 1 gram kemudian ditambahkan aquades hingga volume mencapai $500 \mathrm{~mL}$ dan didapatkan konsentrasi 2000 ppm.

\subsection{Preparasi Sampel larutan Induk Pewarna Tekstil lila (Wantex)}

Larutan induk ini kemudian dilarutka lagi dengan mengambil $25 \mathrm{ml}$ di larutkan dalam $500 \mathrm{ml}$ aquades. Larutan induk ini kemudian digunakan dalam setiap pembuatan larutan pewarna tekstil lila.

\subsection{Penentuan Panjang Gelombang Maksimum Pewarna Tekstil Lila}

Larutan pewarna tekstil lila dengan konsentrasi 50 ppm sebanyak $100 \mathrm{~mL}$ diukur absorbansinya pada variasi panjang gelombang antara $400-600 \mathrm{~nm}$ dengan spektroskopi UV-VIS untuk mendapatkan panjang gelombang maksimumnya.

\subsection{Pembuatan Kurva Standar Untuk Spektroskopi UV-VIS}

Larutan pewarna tekstil lila dengan variasi $\quad 5,10,20,30,40,50,60,70,80,90$,dan
100 ppm (dibuat dengan cara mengencerkan larutan induk 100 ppm dengan aquades) sebanyak $50 \mathrm{~mL}$ diukur absorbansinya dengan spektroskopi UVVIS pada panjang gelombang optimum.

\subsection{Penentuan pH Optimum Adsorpsi Pewarna Tekstil lila (Wantex) \\ Biomassa kangkung sebanyak 0,2 gram dishaker dalam $100 \mathrm{ml}$ larutan pewarna tekstil lila dengan variasi $\mathrm{pH} 3,4$, 5, 6, 7, dan 8 selama 2 jam. Kemudian diukur absorbansinya pada panjang gelombang $536 \mathrm{~nm}$.}

\subsection{Penentuan Waktu Kontak Optimum} Adsorpsi Pewarna Tekstil

Biomassa kangkung sebanyak 0,2 gram dishaker dalam $100 \mathrm{ml}$ larutan pewarna tekstil lila pada $\mathrm{pH}$ optimum dengan variasi waktu kontak 1-180 menit. Setelah selesai pengocokan filtrat diukur absorbansinya pada panjang gelombang $536 \mathrm{~nm}$.

\subsection{Penentuan Pengaruh Adsorpsi Larutan Pewarna Tekstil Lila terhadap Biomassa kangkung}

Larutan induk $50 \mathrm{ppm}$ diambil sebanyak $100 \mathrm{ml}$ di aduk dengan biomassa kangkung sebanyak 0,2 gram pada $\mathrm{pH}$ dan waktu kontak optimum. Setelah selesai pengocokan filtrat diukur absorbansinya. 
menggunakan kisaran panjang gelombang

\section{HASIL PENELITIAN DAN PEMBAHASAN}

\subsection{Penentuan Panjang Gelombang \\ Larutan Pewarna Tekstil Lila Dengan Spektrofotometri UV Vis}

Penentuan panjang gelombang maksimum dilakukan dengan larutan standar pewarna tekstil Lila 100 ppm
400-600 nm dengan alat Spektofotometer UV-VIS Shimadzu dengan melihat nilai absorban tertinggi maka panjang gelombang maksimum dipilih. Panjang gelombang maksimum untuk larutan standar pewarna tekstil lila 100 ppm menggunakan Spektofotometer UV-VIS yaitu $536 \mathrm{~nm}$ (gambar 4.1) dengan interfal 20.

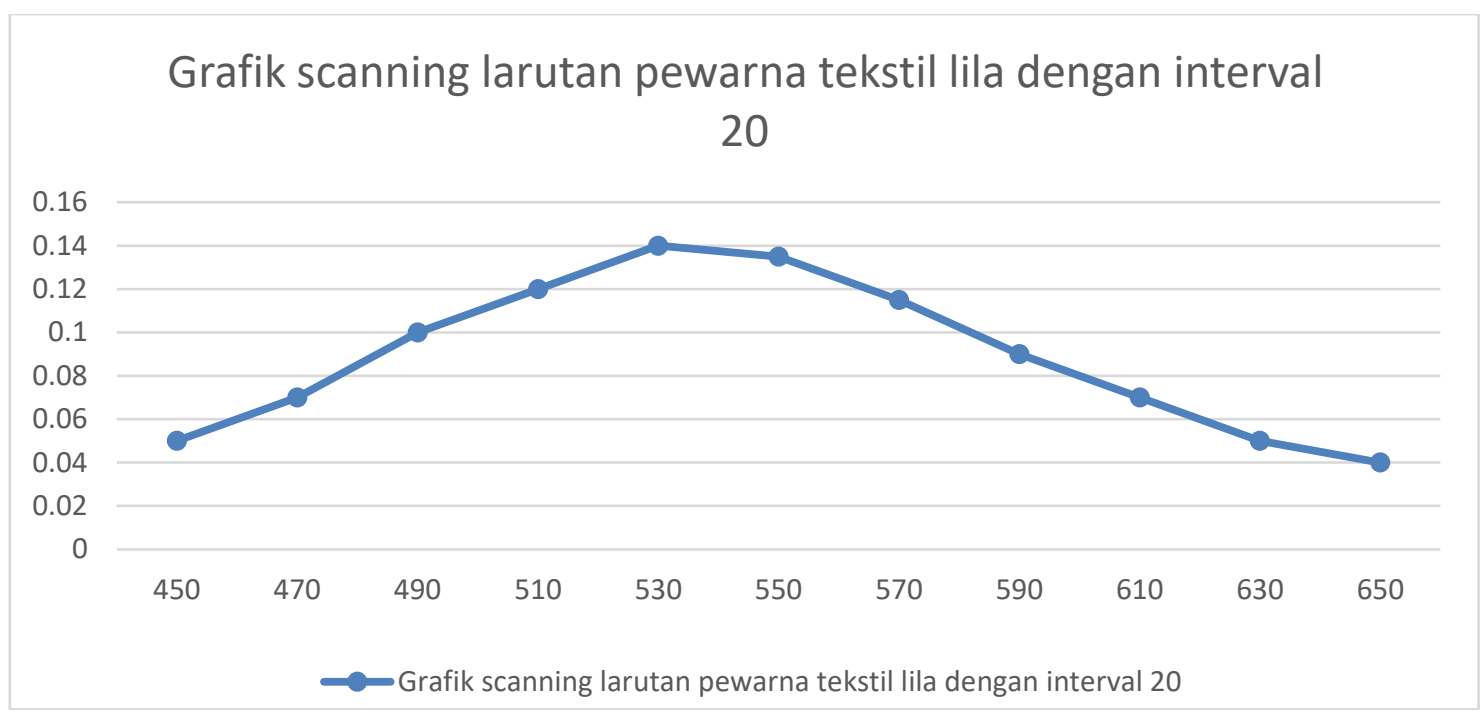

Untuk mendapatkan panjang gelombang yang lebih optimum di lakukan scanning lagi dengan interfal 2 dan di dapat panjang gelombang maksimum $536 \mathrm{~nm}$ 


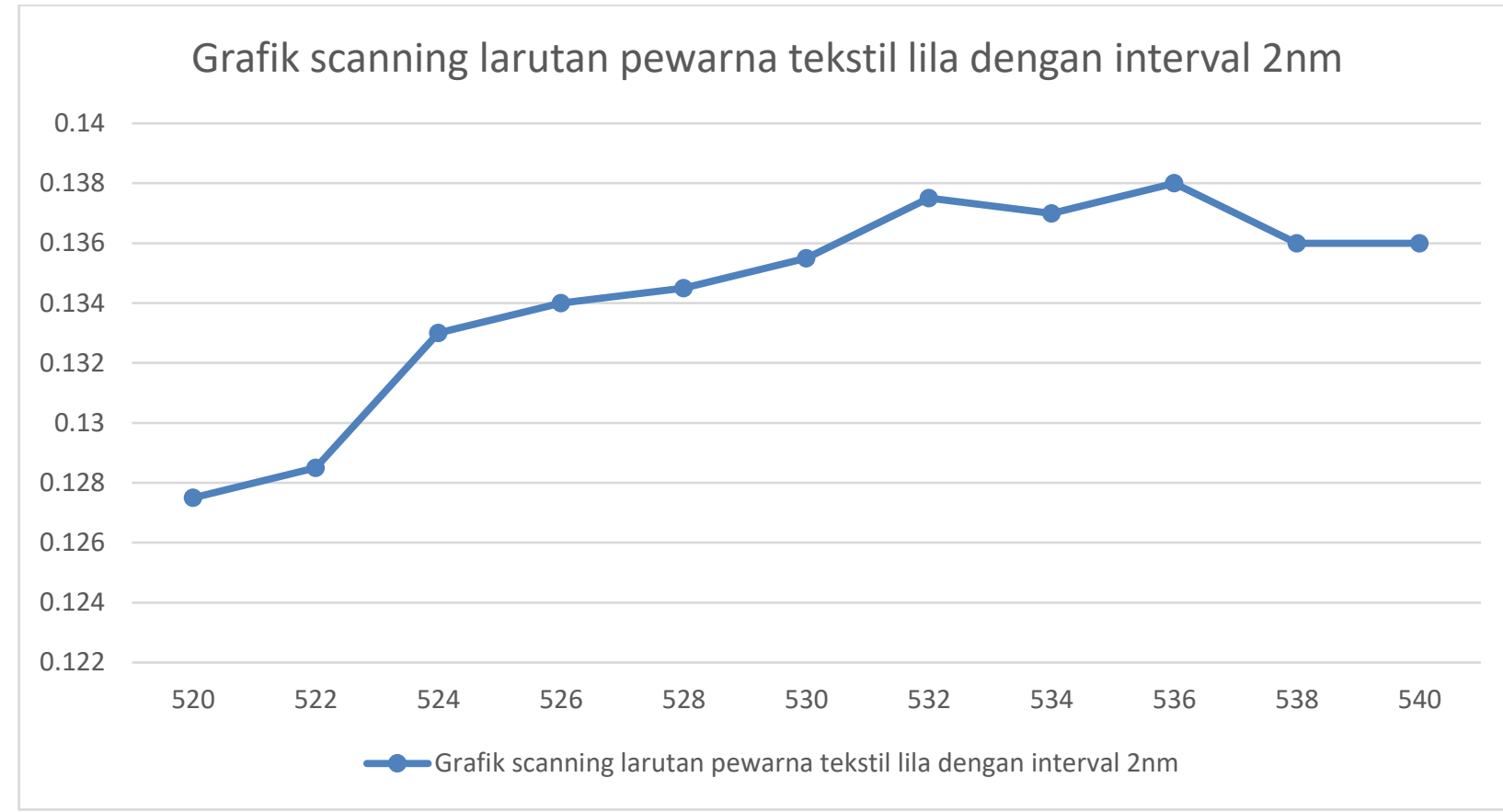

Setelah memperoleh panjang gelombang maksimum diperoleh, dilanjutkan dengan menentukan kurva standar untuk larutan standar, dengan cara pewarna tekstil lila dengan berbagai konsentrasi berjumlah 11 larutan standar. Pembuatan larutan standar berasal dari larutan induk pewarna tekstil lila $100 \mathrm{ppm}$ diencerkan menjadi $50 \mathrm{~mL}$ dengan konsentrasi yaitu 5, 10, 20, 30, 40, 50, 60, 70, 80, 90, 100 ppm. Pengukuran absorban deret standar menggunakan Spektofotometer UV-VIS untuk larutan pewarna tekstil lila menghasilkan kurva persamaan linear antara absorban terhadap pewarna tekstil merah adalah $\mathrm{y}=0,002 \mathrm{x}+$

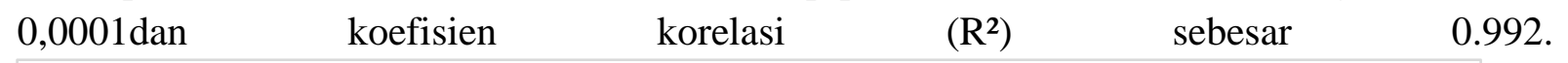

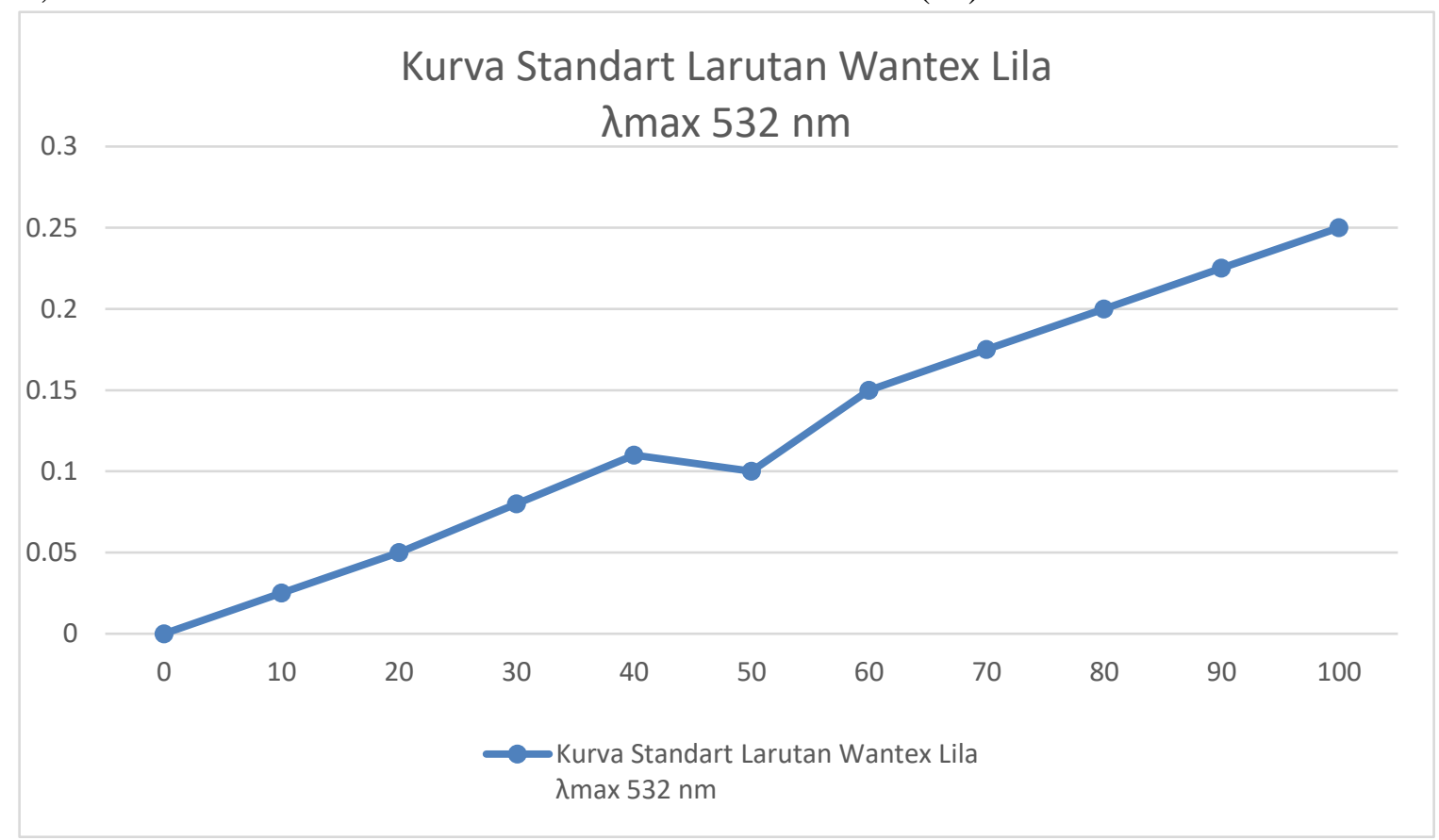

$(0,025 ; 0,05 ; \ldots .$.$) Absorbansi \& (0 ; 10 ; 20 ; 30 ; \ldots .$.$) Kosentrasi Larutan Wantex [ppm]$

3.2 Preparasi Sampel Biomassa Batang Kangkung Air
Untuk mendapatkan biomassa batang kangkung air yang dijadikan 
sebagai adsorben maka batang kangkung air dipotong $5 \mathrm{~cm}$, kemudian dioven pada suhu $100{ }^{\circ} \mathrm{C}$ selama 24 jam sampai diperoleh berat konstan. Setelah itu dihaluskan dan diayak sehingga diperoleh ukuran partikel 270 mesh untuk mendapatkan luas permukaan adsorben yang optimal. Menurut Oscik dan Cooper (1982), efisiensi adsorpsi merupakan fungsi luas permukaan adsorben.

Semakin besar luas permukaan adsorben semakin besar pula kapasitas suatu adsorben dalam mengadsorpsi suatu adsorbat. Sebelum digunakan, terlebih dahulu biomassa batang kangkung air direndam dengan $\mathrm{HCl} \quad 0,01 \quad \mathrm{M}$ sambil disheker selama 1 jam untuk melarutkan logam-logam yang terikat pada biomassa, serta untuk mengaktifasi biomassa agar kemampuannya dalam mengikat ion $\mathrm{Cr}{ }_{2} \mathrm{O}$ 7 2- dan ion $\mathrm{HcrO}_{4}$ - dalam larutan semakin besar karena pada permukaan biomassa tersebut akan banyak terdapat ion $\mathrm{H}+$ yang terikat pada permukaan adsorben akibat ionisasi dari ion $\mathrm{H}+$ dari molekul $\mathrm{HCl}$ yang terlarut dalam air (Danarto dan Artati, 2005).

Karena kondisi biomassa menjadi basah kembali oleh aquades maka biomassa dioven kembali pada suhu $60{ }_{\circ} \mathrm{C}$ selama 5 jam untuk menghilangkan air sampai diperoleh berat konstan.

\section{KESIMPULAN}

Kesimpulan yang dapat diambil dari penelitian ini adalah

1. Semakin besar luas permukaan adsorben semakin besar pula kapasitas suatu adsorben dalam mengadsorpsi suatu adsorbat.

2. Penanggulangan pencemaran air limbah khususnya logamlogam berat yang berasal dari limbah industri tekstil dengan menggunakan biomassa kangkung air.

3. Pada saat reaksi kromat direduksi menjadi $\mathrm{Cr}(\mathrm{II})$ dan kemudian terbentuk menjadi difenilkarbazon, hasil reaksi yang terjadi menghasilkan kompleks dengan warna yang khas.

4. Zat warna tekstil umumnya dibuat dari senyawa azo dan turunannya yang merupakan gugus benzena.

5. Energi adsorpsi merupakan jumlah energi elektrostatik dan energi adsorpsi kimia yang terlibat dalam adsorpsi yang dapat dinyatakan sebagai energi bebas standar adsorpsi.

\section{DAFTAR PUSTAKA}

Adamson. 1990. Physical Chemistry of Surface. New York. John Wiley and Sons Inc.

Ansari, R. 2005. Aplication of Polyaniline and its Composites for Adsorption Recovery of Chromium(VI) from Aquous Solution. Scientific Paper. Chemistry Department. Faculty of Science. Guilan University. Iran. Pp 53-94.

Atkins. 1999. Kimia Fisika Jilid Dua, Erlangga. Jakarta. 
Azis. 2007. Analisis Kandungan Sn, Zn, dan $\mathrm{Pb}$ dalam Susu Kental Manis Kemasan Kaleng Secara Spektrofotometri Serapan Atom. Jurnal Kimia Fakultas Matematika dan Ilmu Pengetahuan Alam. Universitas Islam Indonesia Jogjakarta. Tahun 2007. Jogjakarta.

Darmono. 2008. Logam dalam Sistem Biologi Makhluk Hidup, UI Press, Jakarta.

Dasuki. 1991. Klasifikasi Kangkung Air. http://eyesbeam.wordpress. com/2009/03/ 11/ pengetahuan umum-tentang-kangkungair. Diakses tanggal 29April 2021.

Deman, John M. 1997. Kimia Makanan, edisi dua. ITB. Bandung.

Isminingsih, G.L. Djufri, dan Rassid; 1982. Pengantar Kimia Zat Warna, ITB Bandung.

Kohar, Indrajati. Poppy Hartatie Hardjo, dan Imelda Inge Lika. 2004. Studi Kandungan Logam $\mathrm{Pb}$ dalam Batang dan Daun Kangkung (Ipomoea reptans) yang Direbus dengan Penmahan $\mathrm{NaCl}$ dan Asam Asetat. Jurnal Kimia Sains, vol. 8, no. 3, desember 2004: 8588.

Prasetyawati, Reni. 2007. Uji Kandungan Logam Berat Merkuri (Hg) dan Kadmium (Cd) pada Kangkung Air (Ipomea aquatica Forsk) di Taman Wisata Wendet Malang. Skripsi Jurusan Biologi Fakultas SAINTEK. Universitas Islam Negeri Malang. Malang.

Zaqiyah E.A.H. 2016. Pengaruh Kesetimbangan Adsorpsi Pewarna Tekstil Pada Biomasa Kangkung Air (Ipomoea Aquatica Forsk) Proposal Penelitihan jurusan Kimia MIPA Universitas PGRI Banyuwangi. Banyuwangi. 